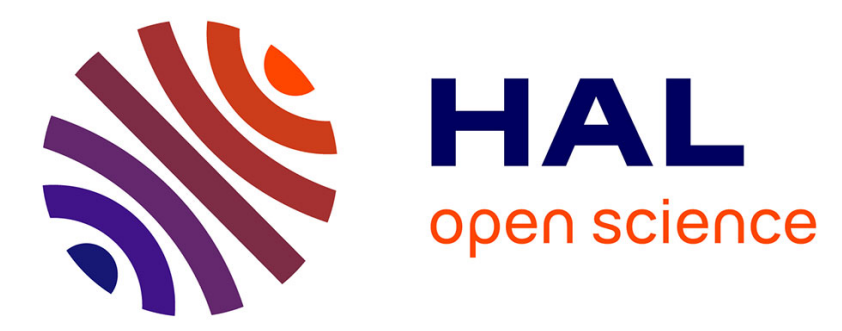

\title{
Lower Jurassic benthic foraminiferal assemblages from shallow-marine platform carbonates of Mallorca (Spain): stratigraphic implications
}

Ana Sevillano, Michel Septfontaine, Idoia Rosales, Antonio Barnolas, Beatriz Bádenas, José María López-García

\section{To cite this version:}

Ana Sevillano, Michel Septfontaine, Idoia Rosales, Antonio Barnolas, Beatriz Bádenas, et al.. Lower Jurassic benthic foraminiferal assemblages from shallow-marine platform carbonates of Mallorca (Spain): stratigraphic implications. Journal of Iberian Geology, 2020, 46 (1), pp.77-94. 10.1007/s41513-019-00117-9 . hal-02947758

\author{
HAL Id: hal-02947758 \\ https://hal.science/hal-02947758
}

Submitted on 24 Sep 2020

HAL is a multi-disciplinary open access archive for the deposit and dissemination of scientific research documents, whether they are published or not. The documents may come from teaching and research institutions in France or abroad, or from public or private research centers.
L'archive ouverte pluridisciplinaire HAL, est destinée au dépôt et à la diffusion de documents scientifiques de niveau recherche, publiés ou non, émanant des établissements d'enseignement et de recherche français ou étrangers, des laboratoires publics ou privés. 
LOWER JURASSIC BENTHIC FORAMINIFERAL ASSEMBLAGES FROM SHALLOW MARINE PLATFORM CARBONATES OF MALLORCA (SPAIN): STRATIGRAPHIC IMPLICATIONS

Ana Sevillano ${ }^{\mathrm{a}}$, Michel Septfontaine ${ }^{\mathrm{b}}$, Idoia Rosales ${ }^{\mathrm{c}}$, Antonio Barnolas ${ }^{\mathrm{c}}$, Beatriz (a) Bádenas $^{\mathrm{d}}$, José María López-García ${ }^{\mathrm{a}}$

a Instituto Geológico y Minero de España (IGME), 07007 Palma de Mallorca, Spain

${ }^{\mathrm{b}}$ University of Lausanne, CH-1015 Lausanne, Switzerland

c Instituto Geológico y Minero de España (IGME), Ríos Rosas 23, 28003 Madrid, Spain

${ }^{\mathrm{d}}$ Departamento de Ciencias de la Tierra, Universidad de Zaragoza, 50009

Zaragoza, Spain

*Corresponding author. Tel: +34 971467020

E-mail address: a.sevillano@,igme.es (A. Sevillano)

\section{Abstract}

The stratigraphic distribution of larger benthic foraminifera and other microfossils recognizable in thin sections has been investigated in three stratigraphic profiles (Son Maina, S'Heretat and Cuevas de Artà) along the Lower Jurassic shallow-water carbonate platform succession (Es Barraca Member) of the Llevant Mountains in the Mallorca Island. Here, the microfossil assemblage contains abundant benthic foraminifera and calcareous algae, including the microproblematic Thaumatoporella parvovesiculifera (Raineri) and the typical Liassic species Palaeodasycladus mediterraneus (Pia), which has allowed a better age constraint of the succession. Four consecutive biozones (scheme of Septfontaine 1984) have been recognized based on the stratigraphic distribution of imperforate foraminifera, which are documented by the first time in the Balearic Basin: Biozone A (interval Zone) is characterized by the occurrence of small Siphovalvulina sp. and Mesoendothyra sp. and some Lituosepta ancestors.

Biozone B (lineage Zone), whose base is marked by the first occurrence of $L$. recoarensis Cati and the top by the first appearance of primitive forms of Orbitopsella. Biozone B/C1 transition, characterized by the presence of very primitive forms of Orbitopsella. Finally, Biozone C1 (lineage Zone) marked by the first occurrence of Orbitopsella aff. primaeva (Henson) but still with L. recoarensis. This distribution of foraminiferal zones is consistent with a Sinemurian age for the Es Barraca Member, with its top very unlikely penetrating into the Pliensbachian. The proposed 
biostratigraphic scheme is comparable with those established for other western Tethyan margins such the High Atlas of Morocco and the Betic Cordillera in southern Spain. The reconstruction of the depositional transect across these profiles shows the progressive lost of the upper biozones towards the northeast, evidencing the existence of significant hiatuses in some sections of the Llevant Mountains domain, and allowing to infer an intra-Pliensbachian early stage of platform fragmentation and erosion, or alternatively non-deposition, probably coeval with progradation of deltaic siliciclastics to the northwest part of the Mallorca island. The new biostratigraphic data presented here highlights the need to review and clarify the current stratigraphic scheme established for the Lower Jurassic of Mallorca.

Key words: Sinemurian-earliest Pliensbachian, benthic foraminifera, biozones, carbonate platform, Es Barraca Member, Balearic Basin

\section{Introduction}

Shallow-marine carbonates of Early Jurassic age developed widely in the western Tethyan margins (Fig. 1). These shallow water carbonate environments experienced important architectural and compositional changes in a context of rifting related with the break-up of Pangea and associated with important circulation, environmental changes and an eustatic sea-level rise (e.g. Zempolich 1993; Ruiz-Ortiz et al. 2004; Massetti et al. 2016; Preto et al. 2017; Rychlinski et al. 2018; Franceschi et al. 2019). These changes are recorded in the lithostratigraphic and biostratigraphic record of the Tethyan platforms. These events coincided also with the faunistic turnover that occurred in the Early Jurassic after the catastrophic Triassic-Jurassic (T/J) boundary mass extinction, which resulted in a gradual recovering and diversification of the shallowwater benthic communities, in which larger benthic foraminifera played a primordial role. So that, the poorly diversified benthic associations of the Hettangian evolved during the early Sinemurian into a more diversified Siphovalvulina- and Textulariadominated assemblages, and finally into more complicated lituolids during the late Sinemurian-Pliensbachian, providing an important biostratigraphic tool (Fig. 2) (Septfontaine 1984, 1988; Bassoullet 1997; Fugagnolli and Loriga 1998; Kabal and Tasli 2003; Mancinelli et al. 2005; Boudagher-Fadel and Bosence 2007; Velic 2007; Gale 2014). 
The Lower Jurassic succession of the Balearic Islands (Fig. 3) is a good representative of the evolution of one of these carbonate platforms associated to all the abovementioned events (Álvaro et al. 1989; Rosales et al. 2018; Sevillano et al. 2019). A comprehensible study of facies analysis and platform evolution of the shallow-water carbonates (Es Barraca Member) has been provided recently in Sevillano et al. (2019). The microfossil content of the Es Barraca Mb was studied in the past by Fallot (1922), Colom (1966, 1970, 1980), and Colom and Dufaure (1962), but not detailed stratigraphic distribution of the recognized foraminifera taxa and biozones was given before. This new micropaleontological study has three aims: First, to establish a foraminiferal biostratigraphy of this shallow-water carbonate succession and to use the distribution of biozones for improving the age resolution of the Es Barraca Member (particularly its top) and, therefore, its relationship with other Lower Jurassic stratigraphic units, for a better definition of the current Lower Jurassic stratigraphic scheme of the Mallorca island. Second, to follow changes, in the studied samples, of the gradual evolution of the Orbitopsellids s.l. during the Lower Jurassic. Third, to use the new biostratigraphic information for getting a better understanding of the tectonostratigraphic evolution of the area during the Lower Jurassic. In addition, this new study will improve the knowledge of the paleogeographical distribution of the Lower Jurassic Foraminifera species in the western Tethys of the eastern Iberian margin, allowing a better comparison with other Tethyan regions.

\section{Geological setting}

The Jurassic sedimentary successions of Mallorca was deposited in a subsiding basin (Balearic Basin, BB) located in the southeastern margin of the Iberian Plate, in a paleogeographic position adjacent to the Ebro High, which was emerged in those times according to recent paleogeographic reconstructions (Fig. 1) (Thierry 2000; Scotese and Schettino 2017). The sedimentary evolution of the Balearic basin during the Jurassic accompanied the opening of the Central Atlantic Ocean and the tectonic evolution of the western Tethyan rifting (Dewey et al. 1973; Dercourt et al. 2000). Although the Balearic archipelago has traditionally been considered as the northeastern prolongation of the Betic Cordillera, new studies suggest that the geodynamic evolution of the area seems to be closer to the early opening of Gulf of Valencia, where recent offshore seismic surveys have brought out the existence of a thick, submerged Mesozoic rift basin, of which, the Balearic archipelago represent the symmetrical southeastern basin 
101 border (Bourrouilh 2016; Etheve et al. 2018). In Mallorca, the biggest island of the

102 archipelago, the rifting evolution during the Jurassic recorded (Álvaro et al. 1989;

103 Barnolas et al. 2010): (1) Lower Jurassic shallow-water carbonate platform successions

104 (Hettangian-Pliensbachian), (2) platform drowning facies during the Toarcian with

105 hardgrounds development, (3) hemipelagic sedimentation during the Toarcian-Aalenian,

106 and (4) typical ammonitico rosso, radiolarites, and mass-wasting deposits indicative of

107 deeper water slope, base of slope and basin environments for the Middle and Upper

108 Jurassic.

109 The lithostratigraphic subdivision of the Jurassic of Mallorca was established by Álvaro

110 et al. (1989). In particular, the general stratigraphic scheme of the shallow water

111 succession deposited during the Early Jurassic includes (Álvaro et al. 1989; Fig. 3): 1)

112 Hettangian sabkha to restricted platform dolomites of the Mal Pas Formation, 2)

113 Sinemurian to Lower Pliensbachian shallow platform carbonates and siliciclastics of the

114 Soller Formation, and 3) Upper Pliensbachian open platform calcarenites and marly

115 limestones of the Es Cosconar Formation. The Soller Formation is in turn subdivided

116 into three members (Fig. 3): Es Barraca Member, made mainly of shallow water

117 peritidal and lagoonal limestones; Sa Moleta Member, made of outer platform shales-

118 siltstones and marly limestones; and Es Racó Member, constituted by deltaic

119 siliciclastics.

120 In the Es Barraca Mb, the focus of this study, the previous surveys (Colom 1970;

121 Álvaro et al. 1989) have cited the presence of Palaeoclasycladus mediterraneus (Pia),

122 Thaumatoporella parvovesiculifera (Raineri), Lituosepta recoarensis Cati, and

123 Orbitopsella praecursor (Gümbel). In base of the previously micropaleontological data

124 and a deduced stratigraphical lateral relationship with the Sa Moleta Mb (lower

125 Carixian), Álvaro et al. (1989) established the age of the Es Barraca Mb as

126 Sinemurian-Lower Pliensbachian (lower Carixian) (Fig. 3). The Sa Moleta Mb is

127 attributed to the Jamesoni and Ibex ammonite zones of the early Pliensbachian (lower

128 Carixian), based on brachiopods and scarce ammonites fauna (Colom 1942; Álvaro et

129 al. 1989), whereas the Es Racó Mb has been attributed to the upper part of the lower

130 Pliensbachian (upper Carixian).

\section{Methods and material}


132 Three stratigraphic sections (Son Maina, S'Heretat and Cuevas de Artà sections) located

133 in the northeast and southeast sectors of Mallorca Island (Llevant Mountains, Fig. 4)

134 have been logged bed-by-bed for the determination of facies and sampling of the Es

135 Barraca Member. The logged facies (F1 to F8 in Fig. 5) consist of limestones and

136 dolostones deposited on tidal flat, subtidal inner platform (including lagoon, internal

137 bars and shoals), muddy open lagoon and muddy outer platform environments, which

138 have been described and reviewed in detail in Sevillano et al. (2019), and therefore,

139 their descriptions are not repeated here. The microfacies description has been made

140 according to the Dunham (1962) nomenclature. Figure 5 shows the detailed lithological

$141 \operatorname{logs}$ of the three studied sections with representation of depositional facies and facies

142 associations, along with the stratigraphic location of the studied samples. Notice that the

143 micropaleontological material for this study comes mainly from the subtidal inner

144 platform facies.

145 The micropaleontological content on foraminifera and other microfossils has been

146 established by the microscopic study of thin sections. A total of 56 thin section samples

147 have been examined. The stratigraphic distribution of the studied samples and the

148 recognized foraminifera and other microfossils are given in Figure 5. The determination

149 of foraminiferal biozones follows the standard biozonation established by Septfontaine

150 (1984), which are widely accepted for the Mediterranean realm. The comparison of this

151 biostratigraphic scheme with other schemes based also on larger benthic foraminifera

152 and with the Lower Jurassic standard ammonite biozones is given in Figure 2.

153 Description of the sections and microfossil assemblages

\section{$154 \quad 4.1$ Son Maina section}

155 The Son Maina section is located southeast of the Manacor town (coordinates:

$15639^{\circ} 30^{\prime} 49^{\prime}$ 'N, $3^{\circ} 15^{\prime} 4^{\prime}$ ' E; Fig. 4) in the south of the Llevant Mountains. It crops out in

157 the inverted flank of a NW-SE fold (Fornós et al. 1984). In this section, the Es Barraca

$158 \mathrm{Mb}$ consists of about $219 \mathrm{~m}$ of tabular limestones overlaying a succession of dolomites

159 belonging possibly to the Mal Pas Formation (Hettangian). The datum at the top of the

160 succession has been placed in a thin ferruginous crust overlaid by crinoidal limestone of

161 the Cosconar Formation (Fig. 5). It is the most representative of the studied sections,

162 showing the thickest and more complete stratigraphic record. In the first $126.5 \mathrm{~m}$, facies 
163 consist mainly of microbial laminites/stromatolites, flat-pebble breccias and intraclastic164 peloidal-oolitic grainstones deposited in peritidal environments (F1, F2 and F3; Fig. 5), interbedded with abundant lime mudstones with scarce restricted fauna (F4) and fossiliferous wackestone-packstone (F6), deposited in shallow restricted and open

167 lagoon environments respectively. Some thin levels of oolitic-peloidal grainstones (F5)

168 representative of internal bars are also present (Sevillano et al. 2019). The succession

169 evolves upward, in the following $88 \mathrm{~m}$ (up to meter 214.5), to a predominance of 170 skeletal mudstone-wackestone (F6, F8), peloidal-oncolitic-foraminiferal wackestone171 packstone (F6, F7) and oolitic-oncolitic grainstones (F5), interpreted as subtidal facies.

172 They are interbedded with a minor amount of fenestral mudstones deposited in peritidal 173 environments (F2), which are noticeably less developed in this upper part of the 174 succession (Fig. 5). This interval ends with the development of a thin ferruginous 175 hardground surface (HG-0 in Fig.4). Above this hardground (HG-0), from meter 214.5 176 to 219 , the facies consist mainly of silty, peloidal-oolitic packstone to grainstone 177 containing larger Foraminifera and large coarse oncoids, suggesting still deposition in a 178 shallow protected carbonate shelf. This interval finishes also with the development of an 179 irregular ferruginous hardground surface (HG-1 in Fig. 5) containing pockets of 180 rounded, centimetric quartzite pebbles on top, suggesting the by-pass of coarse 181 siliciclastics. Above this hardground surface at the meter 219 (HG-1, Fig. 5), the 182 succession follows with a highly covered interval of grainstones rich in echinoderm 183 remains, containing also some internal ferruginous hardgrounds with ammonites and 184 belemnites, deposited in an open shelf and attributed already to the upper Pliensbachian 185 Es Cosconar Fm (Fig. 5).

186 The observed microfossil assemblage (Figs. 5-7) contains, throughout the whole Es 187 Barraca Mb, abundant representatives of Palaeoclasycladus mediterraneus (Pia) and 188 Thaumatoporella parvovesiculifera (Raineri). In the first $106 \mathrm{~m}$ of the section, the 189 Foraminifera assemblage includes: Siphovalvulina, Siphovalvulina evoluted to primitive 190 Pseudofenderina and transition to Valvulina, Valvulina, Pseudofenderina,

191 Everticyclammina praevirguliana Fugagnoli, Meandrovoluta asiagoensis Fugagnoli \& 192 Rettori, Duotaxis, Biokovina, Mesoendothyra, evoluted uncoiled Mesoendothyra with 193 important planispiral nepionic stage, and some ancestor of Lituosepta. The later are 194 uncoiled cylindrical Mesoendothyrids, very small forms, with no internal subdivisions. 195 The first occurrence of Lituosepta recoarensis Cati occurs at the meter 106 and it is 
196 recorded upward for rest the succession along with Siphovalvulina-Valvulina,

197 Everticyclammina and Mesoendothyra. Approximately $160 \mathrm{~m}$ from the base of the 198 succession begin to appear abundant flat morphotypes of Planisepta (Fig. 7i) along with 199 less common Haurania deserta Henson (Fig. 7g). The first appearance of primitive 200 forms of Orbitopsella occurs in the upper part of the succession, from meter 196 to 202, 201 showing this interval a good transition of Lituosepta to Orbitopsella, with small size (2$2023 \mathrm{~mm}$ ) flabelliform to reniform tests but no true discoid. The first occurrence of 203 Orbitopsella primaeva (Henson) occurs at meter 202 (small diameter 4-5 mm), along with cylindrical Lituosepta recoarensis Cati and flat Planisepta, Siphovalvulina and uncoiled Mesoendothyra. The last interval of the succession, between hardgrounds HG0 and HG-1 (meters 214.5 to 219, Fig. 5), contains Orbitopsella primaeva (Henson),

207 Everticyclammina sp. Siphovalvulina (thick wall) and Valvulina. From meter 219, 208 above the hardground surface HG-1 (Fig. 5), the microfacies change to sandy crinoidal 209 packstone with Lagenids (open marine benthic Foraminifera) but not larger complex 210 Foraminifera, indicating an abrupt change to open marine conditions (Es Cosconar Fm).

\subsection{S'Heretat section}

212 The S'Heretat section is located east of the Artà town (coordinates: $39^{\circ} 40^{\prime} 47^{\prime}$ 'N, $2133^{\circ} 25^{\prime} 55^{\prime}$ 'E; Fig. 4) and is $131.5 \mathrm{~m}$ thick. Its lower boundary with the Mal Pas

214 Formation is not exposed, whereas the top boundary is an unconformably contact with 215 the crinoidal limestone of the Es Cosconar Formation. The first $45 \mathrm{~m}$ of the succession 216 are composed mainly of microbial laminites and laminated stromatolites (F2) deposited

217 in peritidal environments, alternating with less abundant lime mudstones with scarce 218 fauna (F4) and oolitic-peloidal grainstones (F5) interpreted to be deposited in subtidal 219 restricted lagoons and internals bars respectively (Sevillano et al. 2019; Fig. 5). Above meter 45 and up to metre 106, the deposits are dominated by subtidal facies made of

221 skeletal mudstone-wackestone and peloidal-oncolitic wackestone-packstone with 222 abundant foraminifera (F6-F8), deposited in shallow open lagoons to open platform 223 environments, interbedded with subordinated oolitic-peloidal-oncolitic grainstones (F5) 224 deposited in internal bars and shoals (Sevillano et al. 2019; Fig. 5). In this interval, 225 some few thin intercalations of peritidal microbial laminites (F2) also occur. Finally, 226 from meter 106 up to 131.5, the succession follows with oolitic-peloidal-oncolitic grainstones (F5) alternating with peloidal-oncolitic-foraminiferal wackestone (F6) deposited in subtidal inner platform environments (Fig. 5). In this interval, only one thin 
229 intercalation of peritidal laminites with flat pebbles (F1) is present approximately at

230 meter 114. Above this interval the succession follows with an interval of grainstones

231 rich in echinoderm remains attributed to the Pliensbachian Es Cosconar Fm (Fig. 5).

232 The microbial-dominated lower part of the succession (up to meter 45) shows very

233 scarce microfossils. In samples from some basal grainy layers Palaeoclasycladus

234 mediterraneus (Pia) has been identified. From meter 46 upward, the microfossil

235 assemblage is notably more diversified and includes: Siphovalvulina, Siphovalvulina to

236 Pseudofenderina transition, Mesoendothyra, Everticyclammina sp. (Fig. 6o), Lituosepta

237 recoarensis Cati (Fig. 7f), Palaeoclasycladus mediterraneus (Pia) and Thaumatoporella

238 parvovesiculifera (Raineri). From meter 87 upward begin to appear also flat

239 morphotypes of Planisepta along with evoluted flabelliform forms of Lituosepta

240 recoarensis Cati, varied forms of Siphovalvulina, and evoluted Mesoendothyra. This

241 assemblage is observed up to metre 131.5. From meter 131.5 upwards, the microfacies

242 change sharply to crinoidal wackestone-packstone with bryozoan and Lagenids, but no

243 complex larger Foraminifera, reflecting an abrupt change to completely different open

244 shelf conditions (Es Cosconar Fm).

\section{$245 \quad 4.3$ Cuevas de Artà section}

246 The Cuevas de Artà section locates close to the Cap Vermell (coordinates: 39³9'55' 'N, $2473^{\circ} 27^{\prime}{ }^{\prime}$ ' E; Fig. 4). At this locality, the measured thickness of the Es Barraca Member is

$248110 \mathrm{~m}$. The lower datum is the contact with a basal dolomite body attributed to the

249 Hettangian (Mal Pas Formation). The top boundary is an unconformity represented by a

250 ferruginous hardground, which is overlaid by red nodular limestone with pelagic thin-

251 shelled bivalves attributed to Bositra, and ammonites of Bajocian age (Álvaro et al.

252 1989). Therefore, at this locality, a hiatus spanning at least from the Pliensbachian to the

253 Bajocian is implied. The whole succession is made of peritidal deposits mainly,

254 consisting of an alternation of black-pebble conglomerates (F1), microbial laminites-

255 stromatolites (F2), intraclastic-peloidal-oolitic grainstones with pedogenic features (F3)

256 deposited in intertidal-supratidal environments, and lime mudstone (F4) deposited in

257 restricted lagoons (Fig. 5). Some few thin oolitic grainstone intercalations (F5),

258 interpreted as internal bars, are also present. 
259 The Cuevas de Artà section shows a low-diversified microfossil assemblage, lacking 260 larger foraminifera. It includes abundant Palaeoclasycladus mediterraneus (Pia) and

261 Thaumatoporella parvovesiculifera (Raineri), along with specimens of Siphovalvulina 262 and Mesoendothyra.

\section{Discussion}

\subsection{Biostratigraphy and age constrains of the Es Barraca Mb}

266 As a general consideration, all of the analysed samples from the three studied sections 267 show microfacies indicative of shallow, lagoonal, inner platform environments, except 268 in two samples belonging to the Es Cosconar Formation, at the top of the Son Maina 269 and S'Hereat sections (Fig. 5), which represent a completely different environment rich 270 in echinoderm remains and Lagenids, indicative of open marine conditions. For the rest 271 of the samples, the small particles are made mainly of microolites or microncoids, 272 which are omnipresent. Other particles are bioclasts, muddy lithoclasts (peloids), 273 benthic Foraminifera, algae, calcimicrobes and large oncoids. The dasycladacean algae

274 Palaeodasycladus occurs throughout all the studied sections associated with the

275 microproblematic Thaumatoporella, both typifying the Liassic protected interior seas of 276 the western Tethys (e.g. BouDagher-Fadel et al. 2001). The widespread occurrence of 277 these genera in the western Tethys was favoured by the continuity of the shallow 278 carbonate platform environments along the whole region. The genus Palaeodasycladus 279 was confined to the Lower and Middle Lias (Hettangian to Pliensbachian), whereas the genus Thaumatoporella had a much longer stratigraphic range.

281 After the pioneer studies of Colom in the past century (Colom 1966, 1970, 1980, Colom 282 and Dufaure 1962), there are not other studies about the biostratigraphy of the Lower 283 Jurassic shallow water successions of the Balearic Islands. However, these authors did 284 not identify benthic foraminiferal assemblages and biozones in these successions. There 285 are, for the Early Jurassic, everal biostratigraphic schemes, based on benthic larger 286 Foraminifera. In this study, the chronobiostratigraphic proposal of Septfontaine (1984) 287 has been adopted for the characterization of the Foraminifera zonal scheme of the 288 studied successions. The comparison of this scheme for the Sinemurian-Pliensbachian 
with other proposed benthic foraminiferal biostratigraphic schemes and with the standard ammonite zones is shown in Figure 2.

291 The analysed samples of the Es Barraca Mb show that larger Foraminifera were diverse in the Balearic region, showing assemblages comparable with others reported from southern Iberia and Morocco (Septfontaine 1984, Azerêdo et al. 2003, BouDagher-

294 Fadel and Bosence 2007). According to the observed Foraminifera assemblages, the

295 three biozones A, B and C1 have been identified (Fig. 8). These biozones could be 296 correlated with those proposed by Septfontaine (1984) for the Lower Jurassic of the 297 High Atlas of Morocco, although there is a modification due to the presence of an 298 interval of transition between biozone B and C1 (Fig. 8). The biostratigraphy and the 299 chronostratigraphic interpretation of the studied successions are shown in Figure 8. The 300 Es Barraca Mb corresponds mainly to biozones $\mathrm{A}, \mathrm{B}$ and $\mathrm{B} / \mathrm{C} 1$ transition, the later 301 observed only in the uppermost part of the unit in the Son Maina section (Fig. 8).

302 The biozone A (Siphovalvulina sp. and Mesoendothyra sp. Interval Zone) has been 303 identified in the three studied sections. This biozone is characterized by the presence of 304 Siphovalvulina and Mesoendothyra along with some Lituosepta ancestors. The upper 305 boundary of this biozone is marked by the first occurrence of Lituosepta recoarensis 306 Cati. In the Son Maina section, the most complete of the three, the biozone A spans 307 from the base of the section up to meter 106. In the S'Heretat section, biozone A spans up to meter 46. In the Cuevas de Artà section, all the succession of the Es Barraca $\mathrm{Mb}$ 309 up to the hardground overlaying the shallow water limestones corresponds to biozone A.

311 The biozone B (Lituosepta recoarensis Lineage Zone) is defined by Septfontaine (1984) 312 as a phylozone spanning from the first occurrence of Lituosepta recoarensis Cati up to 313 the first occurrence of Orbitopsella primaeva (Henson). In the Son Maina section, this 314 biozone starts at meter 106 and spans up to meter 196, where the first primitive forms of 315 Orbitopsella appear. In this biozone Lituosepta recoarensis co-occurs with 316 Siphovalvulina and Mesoendothyra persisting from the underlying biozone. In the upper 317 part of the biozone flat morphotypes of Planisepta and Haurania deserta also occur. In 318 the S'Heretat section, biozone B stars at meter 46 and spans up to the hardground at top 319 of the succession of the Es Barraca Mb, since here Orbitopsella specimens have not 320 been found. In the Cuevas de Artà section, biozone B is absent (Fig. 8). 
321 In the Son Maina section the top of the Es Barraca Mb in represented by the hardground

322 surface HG-0 (Fig. 8). Below this hardground surface, the meters 196 to 214

323 (uppermost part of the Es Barraca $\mathrm{Mb}$ ) are characterized by only small primitive forms

324 of Orbitopsella, suggesting a transitional zone between biozones B and C1 (biozone

$325 \mathrm{~B} / \mathrm{C} 1$ transition in Fig. 8) for this part of the succession, and therefore, for the

326 uppermost Es Barraca Mb (Fig. 8). The biozone C1 (Orbitopsella primaeva Lineage

327 Zone) is present only in the uppermost part of the Son Maina section, above the

328 hardground surface HG-0 which marks the top of the Es Barraca Mb (Fig. 8).

329 BouDagher-Fadel and Bosence (2007) set the first appearance of Everticyclammina

330 praevirguliana in the middle Sinemurian for the western Mediterranean region, whereas

331 according to Velić (2007) it appears already in the late Hettangian. There is a better

332 consensus with the first appearance of Lituosepta recoarensis in the late Sinemurian

333 (Septfontaine 1984, BouDagher-Fadel and Bosence 2007, Velić 2007), having this

334 species a relative well-defined biostratigraphic position in this part of the stage. The

335 first occurrence of Orbitopsella is established in the latest Sinemurian, with $O$.

336 primaeva spanning from the latest Sinemurian to the early Pliensbachian (Septfontaine

337 1984, Velić 2007). According to these data, it can be concluded that the Es Barraca Mb

338 of Mallorca has a Sinemurian age (probably middle-late Sinemurian), biozones A-B.

339 At Son Maina, the most complete section, the uppermost part of the Es Barraca Mb (the

340 last $16 \mathrm{~m}$ below the hardground surface $\mathrm{HG}-0$ ) would correspond to the upper part of

341 the late Sinemurian showing a transition between biozones $\mathrm{B} / \mathrm{C} 1$. This suggests an age

342 not younger than the late Sinemurian for the top of the Es Barraca $\mathrm{Mb}$, implying,

343 therefore, that the top of the Es Barraca Mb did not reached the Pliensbachian, as it has

344 been suggested in earlier studies (Álvaro et al. 1989) (Fig. 9). The interval of shallow-

345 water limestones containing Orbitopsella aff. primaeva between the hardgrounds HG-0

346 and HG-1 (meters 214.5 to 219 , Figs. 5, 8) could range in age from the latest

347 Sinemurian to the early Pliensbachian (early Carixian), biozone C1. The first

348 Orbitopsella aff. primaeva that appear in this interval are very small (diam. 4-6 mm)

349 and primitive compared to the typical $O$. primaeva $(10-15 \mathrm{~mm})$ and are also scarce,

350 which points to preferably latest Sinemurian age. However, the absence of more

351 complex and evolved larger Orbitopsellids in these beds could be in part biased by

352 sorting effects in the carbonate sands (absence of larger particles), implying, therefore, 
353 that an early Pliensbachian age cannot be totally excluded for this interval. More

354 information of this interval in other sections is needed.

\section{$355 \quad 5.2$ Evolutionary considerations}

356 The Jurassic lituolids underwent significant evolutionary changes during the

357 Sinemurian. The most important is the evolution of most of the Early Jurassic lituolids

358 from Mesoendothyra sp. (Septfontaine 1984, 1988). One of the proposed evolutionary

359 lines evolving from this form in the late Sinemurian resulted in the Orbitopsellids

360 following this changes: Mesoendothyra sp. - Lituosepta recoarensis - Orbitopsella

361 primaeva - O. praecursor (Septfontaine 1984, 1988). In the studied samples, this

362 gradual evolution of the Orbitopsellids s.l. during the Sinemurian could be observed in

363 three steps (step 1 to 3 in Fig. 8), which represent evolutionary relatively stable

364 morphogenetic (architectural) innovations in a "population genetic" setting with many

365 transitions, as observed in the Son Maina section. The biozonation proposed in this

366 study is based on these steps (phylozones), and their equivalence with the biozones is

367 shown in figure 8.

368 In the Son Maina and S'Heretat sections, the evolutionary steps are observed as follows:

369 Step 1, meters 24-106, characterized by Lituosepta ancestor (uncoiled cylindrical

370 Mesoendothyrids), with no internal subdivisions, important plani nepionic stage, and

371 very small forms. Step 2, meters 106-161, characterized by the first apparition of

372 vertical radial partitions, true cylindrical Lituosepta recoarensis with rare flat

373 "Planisepta-like" types. Step 3, meters 161-214.5, characterized by the diversification

374 of the shape and external contour of the test with internal complications. With

375 advanced Lituosepta to Orbitopsella with reniform to discoidal test and internal

376 complications. The flat morphotypes "Planisepta-like" become frequent. It is observed

377 many transitions between the different morphotypes but with a general trend to increase

378 the chamber volume for hosting symbionts. To go further in the mode of evolution,

379 more data from bed-by bed sampling are needed.

5.3 Stratigraphic implications 
384 Acknowledgements

385 This paper is a contribution to the research project RTI2018-093613-B-100 funded by 386 the Spanish Ministry of Science, Innovation and Universities.

\section{References}

389 Álvaro M., Barnolas A., Cabra P., Comas-Rengifo M.J., Fernández-López S.R., Goy 390 A., Del Olmo P., Ramírez del Pozo J., Simo A., Ureta S. (1989). El Jurásico de 391 Mallorca (Islas Baleares). Cuadernos de Geología Ibérica, 13, 67-120.

392 Barnolas A., Simò J.A., Rosales I., Gil-Peña I., Sevillano A., Armendáriz M. (2010). 393 Revisión de la información paleogeográfica del Jurásico de Mallorca basada en datos 394 sedimentológicos y en el análisis de cuenca. In J.I. Ruiz-Omeñaca, 1. Piñuea, J.C. García395 Ramos (Eds). Comunicaciones del V Congreso del Jurásico de España. Museo del 396 Jurásico de Asturias, pp 163.

397 Boudagher-Fadel M.K., Bosence, D.W.J. (2007). Early Jurassic benthic foraminiferal 398 diversification and biozones in shallow-marine carbonates of western Tethys.

399 Senckenbergiana Lethaea, 87, 1-39.

400 Bourrouilh, R. (2016). The Balearic Islands in the Alpine Orogeny. Boletín Geológico $y$ 401 Minero, 127(2/3), 527-546.

402 Colom, G. (1942). Sobre nuevos hallazgos de yacimientos fosilíferos del Lias medio y 403 superior en la Sierra Norte de Mallorca. Boletín de la Real Sociedad Española de 404 Historia Natural, 11, 221-265.

405 Colom, G. (1966). Dos niveles micropaleontológicos interesantes en el Lias inferior del 406 Sur de España y baleares. Acta Geologica Hispanica, 1(3), 15-18.

407 Colom, G. (1970). Estudio litológico y micropaleontológico del Lías de la Sierra Norte 408 y porción central de la isla de Mallorca. Memorias de la Real Academia de la Ciencias 409 exactas, fisicas y naturales de Madrid, Tomo XXIV, Mem 2. 
410 Colom, G., Dufaure, P. (1962). Présence de la zone à Palaeodasycladus mediterraneus 411 (Pia) dans le Lias moye du Pla de Cuber (Majorque). Comptes Rendus de l'Académie 412 des Sciences Paris, 12, 2617-2619.

413 Dercourt, J., Gaetani, M., Vrielynck, B., Barrier, E., Biju-Duval. B,, Brunet, M.F., 414 Cadet, J.P., Crasquin, S., Sandulescu, M. (Eds) (2000), Atlas Peri-Tethys, 415 Palaeogeographical maps, I-XX, CCGM/CGMW, Paris.

416 Dewey, J.F., Pitman, W.C., Ryan, W.B.F., Bonnin, J. (1973). Plate tectonics and the 417 evolution of the Alpine system. Geological Society of America Bulletin, 84, 3137-3180.

418 Dunham, R.J. (1962). Classification of carbonate rocks according to depositional texture. 419 In Classification of carbonate rocks. W.E. Ham (Ed), AAPG Mem 1 (pp. 108-121).

420 Etheve, N., Mohn, G., Frizon de Lamotte, D., Roca, E., Tugend, J., Gómez-Romeu, J., 421 (2018). Extreme Mesozoic Crustal Thinning in the Eastern Iberia Margin: The Example 422 of the Columbrets Basin (Valencia Trough). Tectonics, 37(2), 1-27.

423 Fallot, P. (1922). Étude geologique de la sierra de Majorque. Thése détat. Libr.

424 Polytechnique Ch. Béranger, Paris i Liège.

425 Franceschi, M., Dal Corso, J., Cobianchi, M., Roghi, G., Penasa, L., Picotti, V., Preto, N.

426 (2019). Tethyan carbonate platform transformation during the Early Jurassic (Sinemurian427 Pliensbachian, Southern Alps): Comparison with the Late Triassic Carnian Pluvial 428 Episode. Geological Society of America Bulletin, 131, 1255-1275.

429 Fugagnoli, A., Loriga Broglio, C. (1998). Revised biostratigraphy of Lower Jurassic 430 shallow water carbonates from the Venetian Prealps (Calcari Grigi, Trento Platform, 431 Nothern Italy). Studi Trentini di Science Naturali - Acta Geologica, 73, 35-73.

432 Fornós, J., Rodriguez-Perea, A., Sabat, F. (1984). El mesozoico de la Serra de Son 433 Amoixa (Serres de Llevant, Mallorca). I Congreso Español de Geología. Tomo 1, pp $434 \quad 173-185$.

435 Gale, L. (2014). Lower Jurassic foraminiferal biostratigraphy of Podpeč Limestone 436 (External Dinarides, Slovenia). Geologija, 57, 119-146.

437 Kabal, Y., Tasli, K. (2003). Biostratigraphy of the Lower Jurassic carbonates from the 438 Aydinick area (Central Taurides, S. Turkey) and morphological analysis of Lituolipora 439 Termieri (Hottinger, 1967). Journal of Foraminiferal Research, 33, 338-351. 
440 Mancinelli, A., Chiocchini, M., Chiocchini, R.A, Romano, A. (2005). Biostratigraphy of

441 Upper Triassic-Lower Jurassic carbonate platform sediments of the central-southern

442 Apennines (Italy). Rivista Italiana di Paleontologia e Stratigrafia, 111, 271-283.

443 Masetti, D., Figus, B., Jenkyns, H.C., Barattolo, F., Mattioli, E., Posenato, R. (2017).

444 Carbon-isotope anomalies and demise of carbonate platforms in the Sinemurian (Early

445 Jurassic) of the Tethyan region: evidence from the Southern Alps (Northern Italy).

446 Geological Magazine, 154, 625-650.

447 Preto, N., Breda, A., Dal Corso, J., Franceschi, M., Rocca, F., Spada, C., Roghi, G. (2017).

448 The Loppio Oolitic Limestone (Early Jurassic, Southern Alps): A prograding oolitic body

449 with high original porosity originated by a carbonate platform crisis and recovery. Marine

450 Petroleum Geology, 79, 394-411.

451 Rosales, I., Barnolas, A., Goy, A., Sevillano, A., Armendáriz, M., López-García, J.M.

452 (2018). Isotope records (C-O-Sr) of late Pliensbachian-early Toarcian environmental 453 perturbations in the westernmost Tethys (Majorca Island, Spain). Palaeogeography

454 Palaeoclimatololy Palaeoecology, 497, 168-185.

455 Ruiz-Ortiz, P.A., Bosence, D.W., Rey, J., Nieto, L.M.; Castro, J.M., Molina, J.M.

456 (2004). Tectonic control of facies architecture, sequence stratigraphy and drowning of a 457 Liassic carbonate platform (Betic Cordillera, Southern Spain). Basin Research, 16, 235458257.

459 Rychliński, T., Uchman, A., Gaździcki, A. (2018). Lower Jurassic Bahamian-type 460 facies in the Choč Nappe (Tatra Mts, West Carpathians, Poland) influenced by 461 palaeocirculation in the Western Tethys. Facies, 64, 15.

462 Sevillano, A., Rosales, I., Bádenas, B., Barnolas, A., López-García J.M. (2019). Spatial 463 and temporal facies evolution of a Lower Jurassic carbonate platform, NW Tethyan 464 margin (Mallorca, Spain). Facies, https://doi.org/10.1007/s10347-018-0545-0.

465 Scotese, C.R., Schettino, A. (2017). Late Permian-Early Jurassic Paleogeography of 466 Western Tethys and the World. In: Permo-Triassic Salt Provinces of Europe, North 467 Africa and the Atlantic Margins. Elsevier, pp 57-95.

468 Septfontaine, M. (1984). Biozonation (a l'aide des Foraminifères imperforés) de la 469 plate-forme interne carbonatée liasique du Haut Atlas (Maroc). Revue de 
471 Septfontaine, M. (1988). Vers une classification évolutive des lituolidés (Foraminifères) 472 jurassiques en milieu de plate-forme carbonatée. Revue Paléobiologie Vol Spec 2, 473 Benthos'86, pp. 229-256.

474 Thierry, J. (2000). Late Sinemurian (193-191 Ma). In: J. Dercourt, M. Gaetani, B. 475 Vrielynck, E. Barrier, B. Biji-Dubal, M.F. Brunet, J.P. Cadet, S. Crasquin, M. 476 Sandulescu (Eds), Atlas Peri-Tethys. Palaeogeographical Maps explanatory notes. 477 Commission for the Geologic Map of the World, Paris, pp 49-59.

478 Velić, I. (2007). Stratigraphy and palaeobiogeography of Mesozoic benthic foraminifera 479 of the Karst Dinarides (SE Europe). Geologia Croatica, 60, 1-113.

480 Zempolich, W.G., (1993). The drowning succession in Jurassic carbonates of the 481 Venetian Alps, Italy, a record of supercontinent breakup, gradual eustatic rise, and 482 eutrophication of shallow water environments. In: R.G. Loucks, J.F. Sarg (Eds.), 483 Carbonate Sequence Stratigraphy: Recent Developments and Applications. AAPG 484 Memoir, 57 (pp. 63-105).

Figure captions

487 Figure 1: Palaeogeographical map of the western Tethys for the Sinemurian-earliest 488 Pliensbachian (modified from Dercourt et al. 2000) showing the palaeogeographical 489 location of the study area. Yellow star: Location of this study area (BB: Balearic Basin). 490 Red dots: Location of other neighbouring basins (HA: High Atlas; IbR: Iberian Range; 491 BC: Betic Cordillera; ApCP: Appennine carbonate platform; DiCP: Dinaric carbonate 492 platform).

493 Figure 2: Comparison between the standard ammonites biozones and various benthic 494 foraminiferal biostratigraphic schemes for the Sinemurian-Pliensbachian interval 495 proposed for different carbonate platforms of the Western Tethys.

496 Figure 3: General chronostratigraphic chart of the Lower Jurassic of Mallorca with 497 indication of the defined lithostratigraphic units. Modified from Álvaro et al. (1989). 
498 Figure 4: Simplified geological map of Mallorca with the location of the three studied 499 stratigraphic sections. The distances between stratigraphic sections (SH: S'Heretat; CA: 500 Cuevas de Artá; MAI: Son Maina) are shown as today, without restoring the tectonic 501 shortening.

502 Figure 5: Detailed stratigraphic logs of the Es Barraca Mb in the Son Maina, S'Heretat 503 and Cuevas de Artà sections, with location of the studied samples, distribution of 504 benthic foraminifera and algae, and interpretation of the facies associations and facies 505 types (F1 to F8).

506 Figure 6: Pictures of representative microfossils from the studied sections. a

507 Palaeodasycladus mediterraneus (Pia). b Palaeodasycladus mediterraneus (Pia)

508 (yellow arrow) and lituolids (red arrow) c Palaeodasycladus mediterraneus (Pia). d-f

509 Thaumatoporella parvovesiculifera (Raineri). g-i Siphovalvulina sp. j-m

510 Mesoendothyra sp. n-o Everticyclammina praevirguliana Fugagnoli. p Duotaxis sp.

511 Figure 7: Pictures of representative microfossils from the studied sections. a Biokovina 512 sp. b-f Lituosepta recoarensis Cati. g Haurania deserta Henson. h Haurania sp. (red 513 arrow) and Lituosepta recoarensis Cati (yellow arrow). $\mathbf{i}-\mathbf{j}$ Planisepta morphotype 514 (yellow arrow). k-m Orbitopsella aff. primaeva Henson. n Meandrovoluta asiagoensis 515 Fugagnoli \& Rettori.

516 Figure 8: Distribution of benthic foraminiferal biozones of the Es Barraca $\mathrm{Mb}$ in the 517 Son Maina, S'Heretat and Cuevas de Artà sections (Llevant Mountains domain, 518 Mallorca), based on the biozonation scheme proposed by Sepfontaine (1984). The steps 5191 to 3 (phylozones) represent evolutionary stages of the larger lituolids based on 520 morphological transitions from Mesoendothyrids to Orbitopsellids s.l.

$521 \quad$ Figure 9 ...??? 


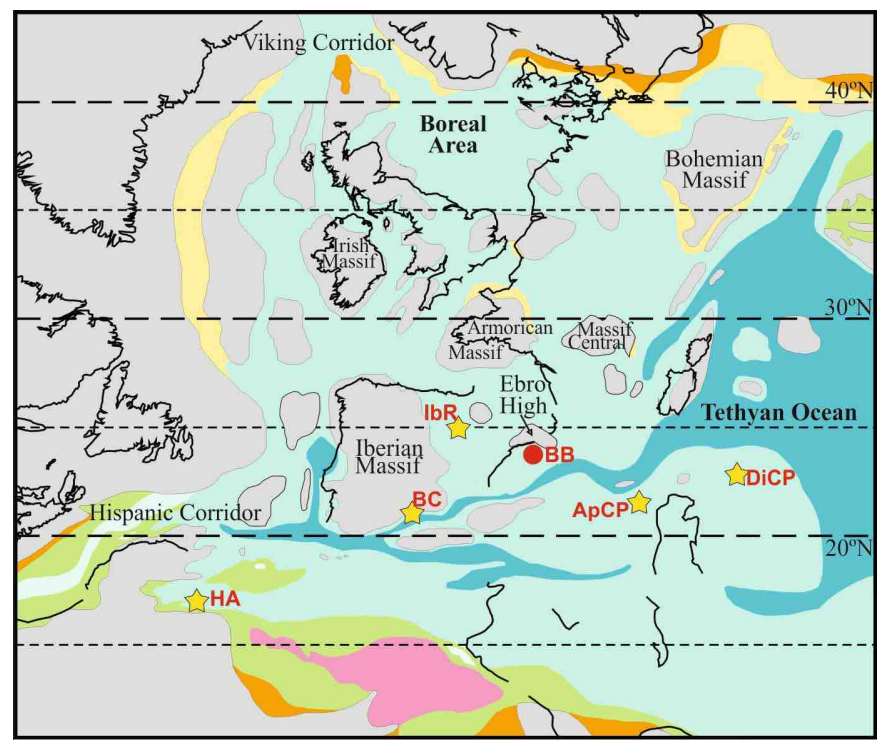

DEPOSITIONAL ENVIRONMENTS:

Exposed landmasses

Fluviatile, lacustrine

fluvio-lacustrine

Hypersaline

Coastal marine, shallow marine (terrigenous)

Shallow environments with

Epicontinental platforms

Shallow environments with

Deep marine and fluctuating salinities

oceanic basins

2 BB (Balearic Basin). This study

HA (High Atlas)

IbR (Iberian Range)

ApCP (Appennine Carbonate Platform)

DiCP (Dinaric Carbonate Platform) 


\begin{tabular}{|c|c|c|c|c|c|}
\hline \multirow{5}{*}{ 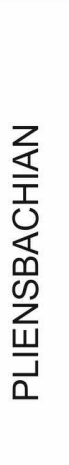 } & spinatum & E Pseudocyclammina liassica & \multirow[b]{2}{*}{ L. termieri } & \multirow{2}{*}{$\begin{array}{l}\text { P. liassica } \\
\text { O. praecursor - } \\
\text { P. liassica }\end{array}$} & \\
\hline & margaritatus & $\begin{array}{l}\text { Paleomayncina termieri and } \\
\text { Planisepta compressa }\end{array}$ & & & \\
\hline & davoei & C2 Orbitopsella praecursor & O. praecursor & O. praecursor & \\
\hline & ibex & \multirow{3}{*}{ Orbitopsella primaeva } & \multirow{3}{*}{ O. primaeva } & \multirow{3}{*}{ O. primaeva } & \multirow{3}{*}{ L. compressa } \\
\hline & jamesoni & & & & \\
\hline \multirow{6}{*}{ 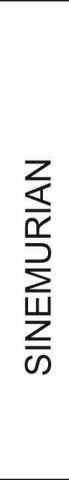 } & raricostatum & & & & \\
\hline & oxynotum & \multirow{2}{*}{ Lituosepta recoarensis } & \multirow{5}{*}{ L. recoarensis } & L. recoarensis & $\begin{array}{l}\text { L. recoarensis \& } \\
\text { Orbitopsella spp. }\end{array}$ \\
\hline & obtusum & & & \multirow{4}{*}{ Mesoendothyra } & \multirow{2}{*}{ E. praevirguliana } \\
\hline & turneri & \multirow{3}{*}{$\begin{array}{l}\text { Siphovalvulina sp. } \\
\text { and Mesoendothyra sp. }\end{array}$} & & & \\
\hline & semicostatum & & & & \multirow{2}{*}{ S. colomi } \\
\hline & bucklandi & & & & \\
\hline & & Septfontaine (1984) & $\begin{array}{l}\text { Kabal \& Tasli } \\
(2000)\end{array}$ & $\begin{array}{l}\text { Velic (2007), } \\
\text { Gale (2014) }\end{array}$ & $\begin{array}{l}\text { BouDagher-Fadel } \\
\text { \& Bosence (2007) }\end{array}$ \\
\hline & & High Atlas (Morocco) & $\begin{array}{l}\text { Central Taurides } \\
\text { (Turkey) }\end{array}$ & $\begin{array}{l}\text { Adriatic Carbonate } \\
\text { Platform } \\
\text { (Slovenia-Croatia) }\end{array}$ & $\begin{array}{l}\text { Betics and Iberian Basi } \\
\text { (Spain); Gibraltar; } \\
\text { Tunisia; Greece; Italy. }\end{array}$ \\
\hline
\end{tabular}




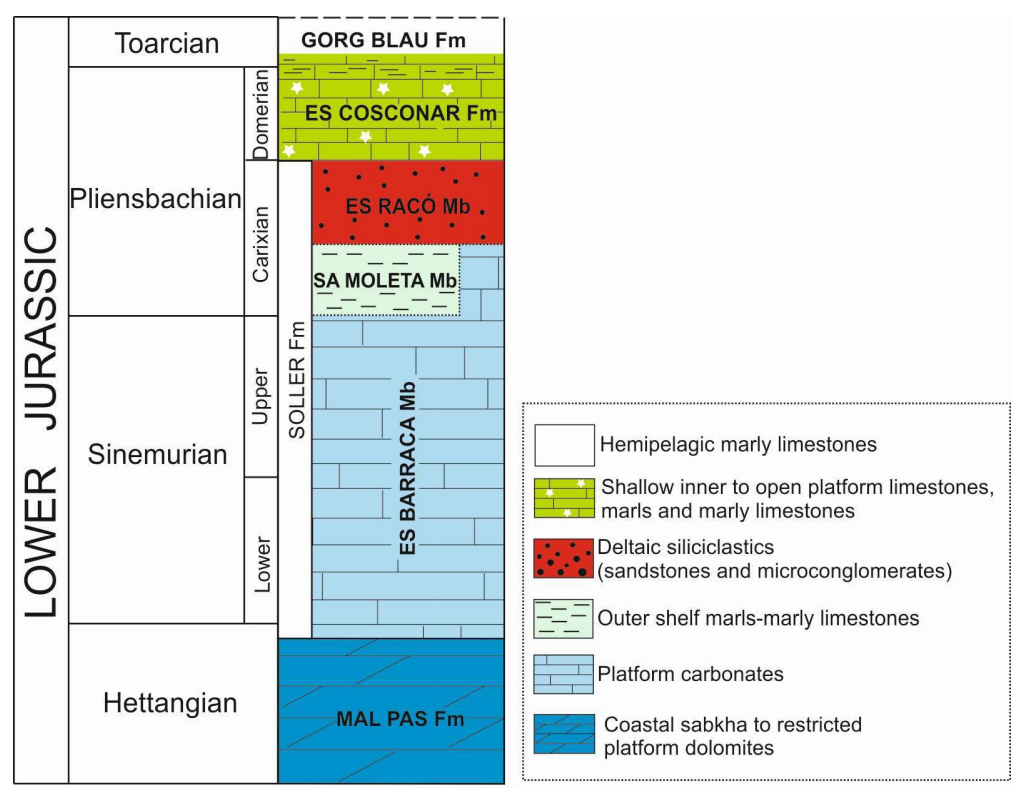

MAJORCA ISLAND

(Alvaro et al. 1989) 


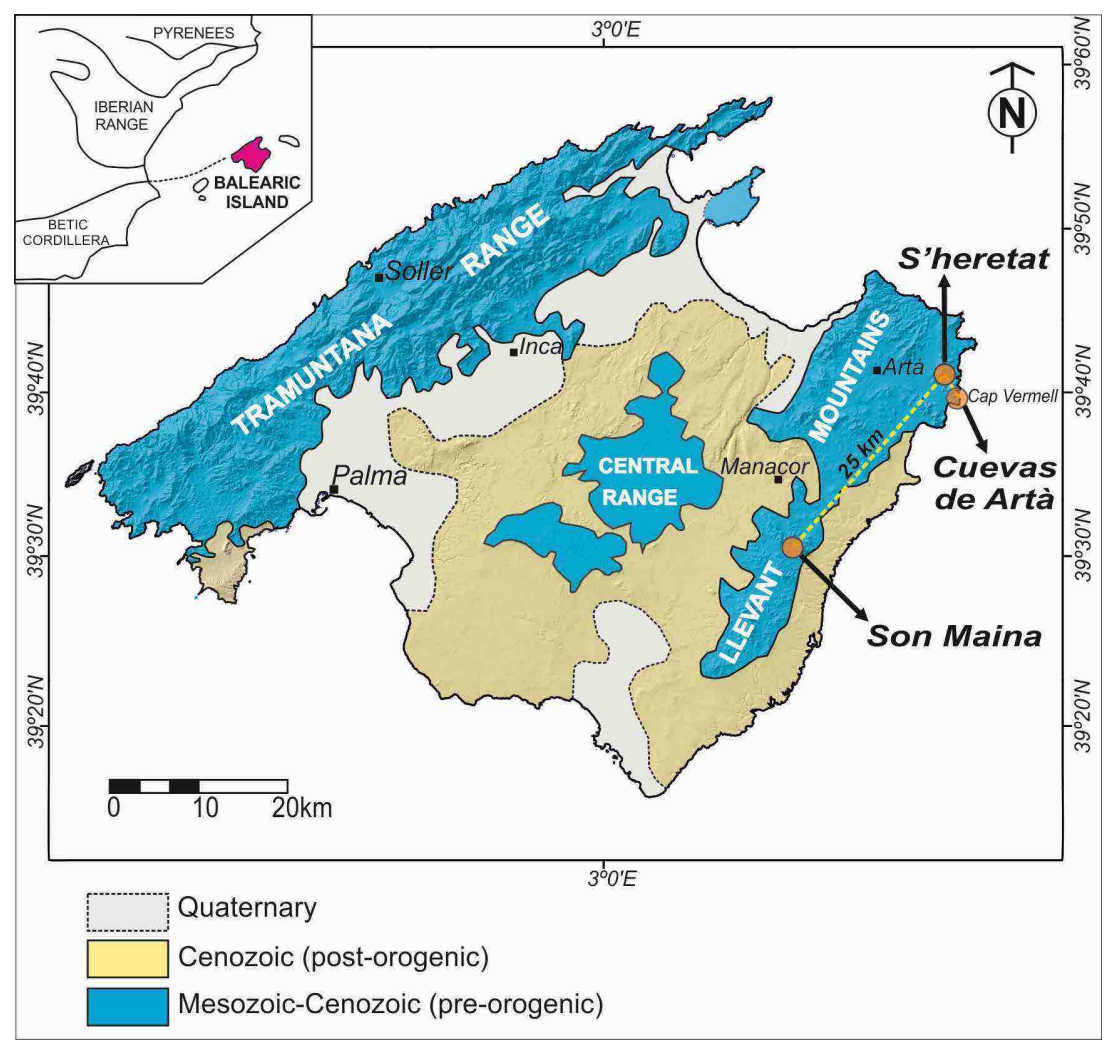




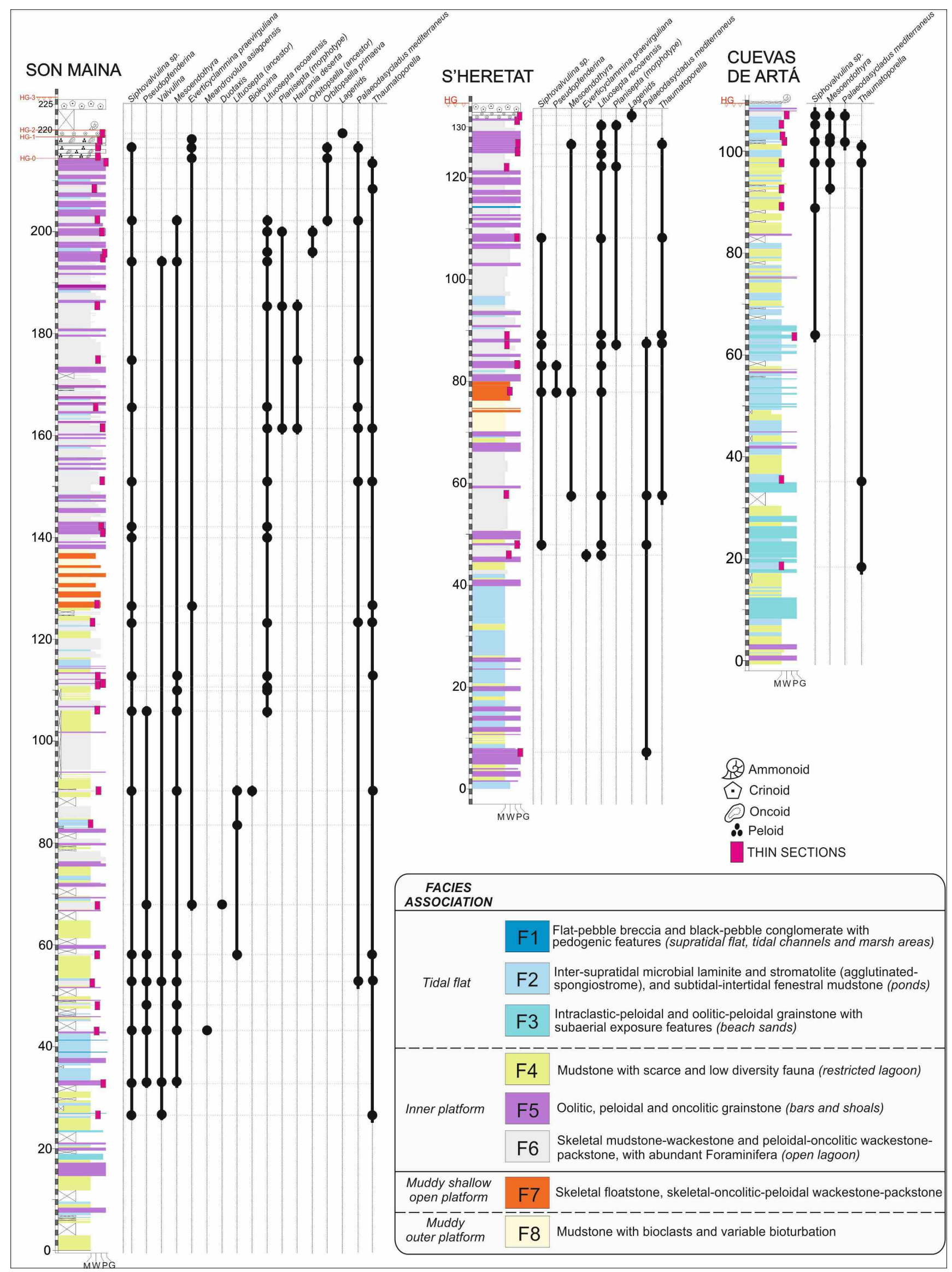




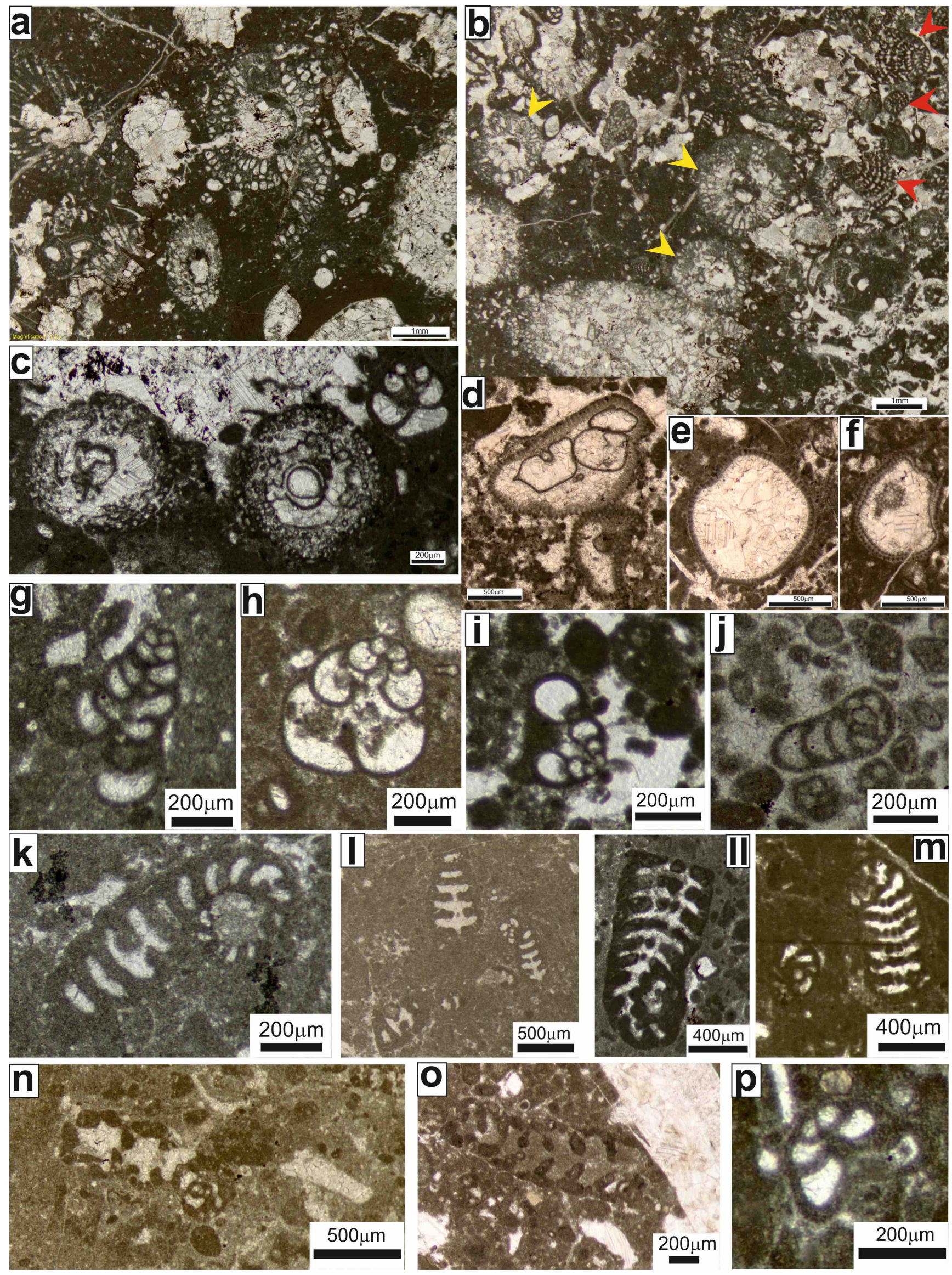



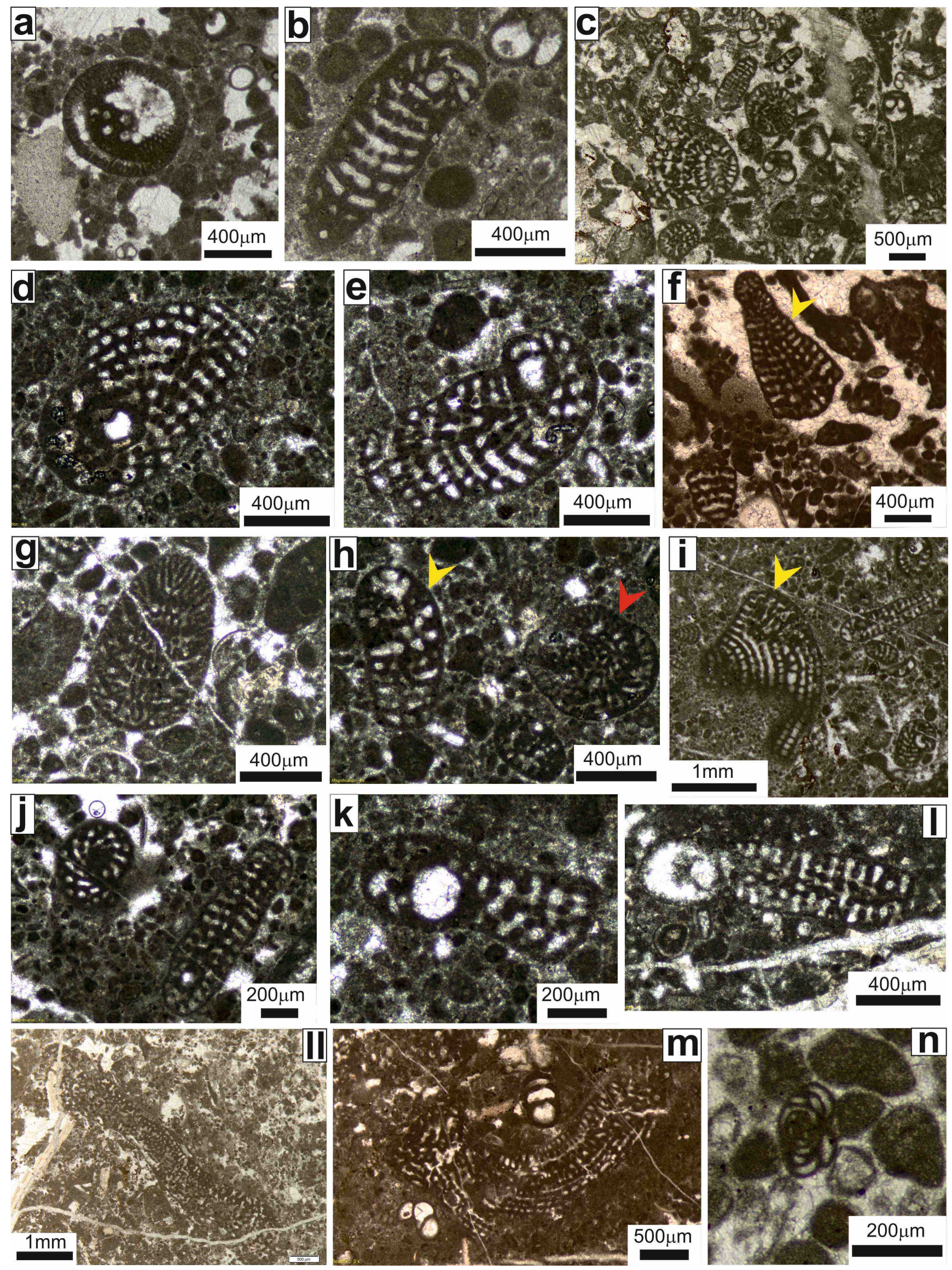


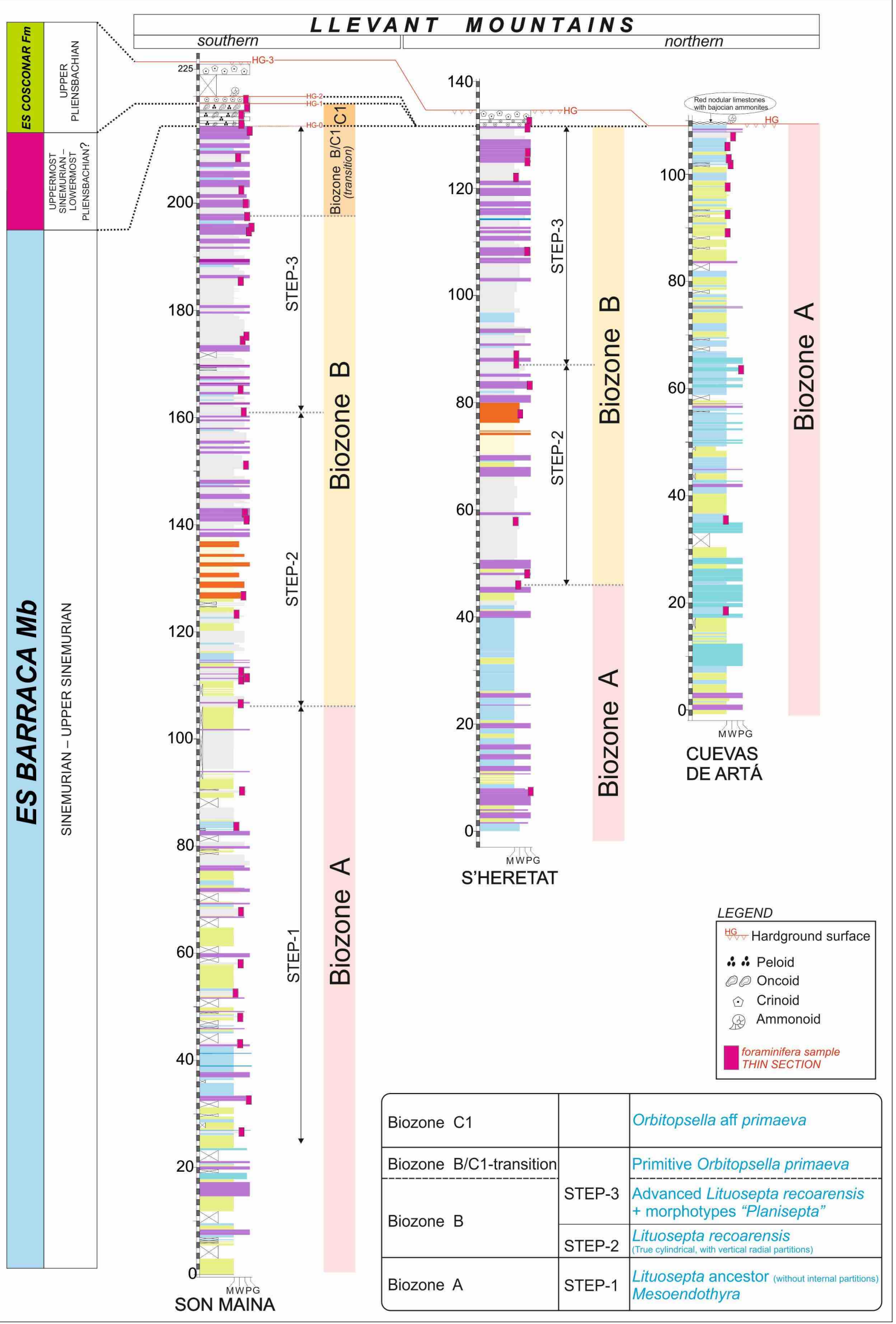

